\title{
Cultured ABAlone BLISTER PEARLS FROM NeW ZEALAND
}

By Cheryl Y. Wentzell

The successful culturing of abalone pearls has been known since French scientist Louis Boutan's experimentation in the late 1890s, but commercial production has been achieved only in recent decades. The use of New Zealand's Haliotis iris, with its colorful and iridescent nacre, has had the strongest recent impact on this industry. Empress Abalone Ltd. is producing large, attractive cultured blister pearls in $\mathrm{H}$. iris. The first commercial harvest in 1997 yielded approximately 6,000 jewelry-quality cultured blister pearls, 9-20 $\mathrm{mm}$ in diameter, with vibrant blue, green, purple, and pink hues. Examination of 22 samples of this material by standard gemological and advanced testing methods revealed that the presence and thicknesses of the conchiolin layers had a significant impact on face-up appearance. Empress Abalone Ltd. is also experimenting with producing whole free-formed cultured pearls in this gastropod mollusk.

\section{ABOUT THE AUTHOR}

Ms. Wentzell (cwentzell@giagtl.org) is a senior staff gemologist in Identification Services at the GIA Gem Trade Laboratory in Carlsbad, California.

Please see acknowledgments at the end of the article.

Gems \& Gemology, Vol. 34, No. 3, pp. 184-200

(C) 1998 Gemological Institute of America

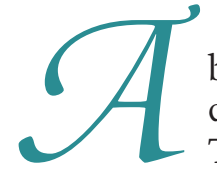

balone pearls are highly prized for their rarity, dynamic colors, and remarkable iridescence. Their unusual shapes-often conical-and potentially large sizes make these pearls especially well suited for designer jewelry. The beauty of these rare pearls has spawned several attempts at culturing, recorded as far back as the late 19th century. However, these early attempts encountered many obstacles. Only recently have researchers begun to overcome the challenges and difficulties presented by abalone pearl culture. One company, Empress Abalone Ltd. of Christchurch, New Zealand, is successfully culturing brightly colored blister pearls within New Zealand's Haliotis iris (figure 1). These assembled cultured blister pearls are marketed under the international trademark, Empress Pearl ${ }^{\circ}$ (or Empress Abalone Pearl ${ }^{\circ}$ in the U.S.). The company is also pursuing the commercial production of whole spherical cultured abalone pearls.

This article will focus on the history, production, marketing, and identifying characteristics of cultured and assembled blister pearls produced by Empress Abalone Ltd. Except where referenced otherwise, information was obtained through personal communication with the owners, Liz and Michael McKenzie, from 1996 through 1998.

\section{HISTORY OF ABALONE PEARL CULTURE}

The successful culturing of abalone pearls has been elusive because of the difficulty of farming and nucleating abalone. The first cultured abalone blister and spherical pearls were experimentally produced in the late 1890s, by French scientist Louis Boutan using the European ormer abalone Haliotis tuberculata (Fankboner, 1991, 1995). Four decades later, La Place Bostwick claimed to have cultured both blister and whole free-formed pearls in abalone from California (Bostwick, 1936). Bostwick's work was succeeded by that of Japanese scientist Dr. Kan Uno during the mid-1950s. Uno 
Figure 1. Since they were first introduced to the international gem market in 1996, cultured abalone

blister pearls from New Zealand have appeared in many pieces of fine jewelry. This $18 \mathrm{~K}$ gold and palladium pendant (actually a hidden clasp) is set with

a $15 \mathrm{~mm}$ "Gem" grade Empress Pearl' ${ }^{\circ}$. The

Tahitian black pearls in the necklace are graduated from $11.5 \mathrm{~mm}$ to 15.25 $\mathrm{mm}$. Designed and manufactured by Richard Kimball, Denver, Colorado; photo (C) Azad.

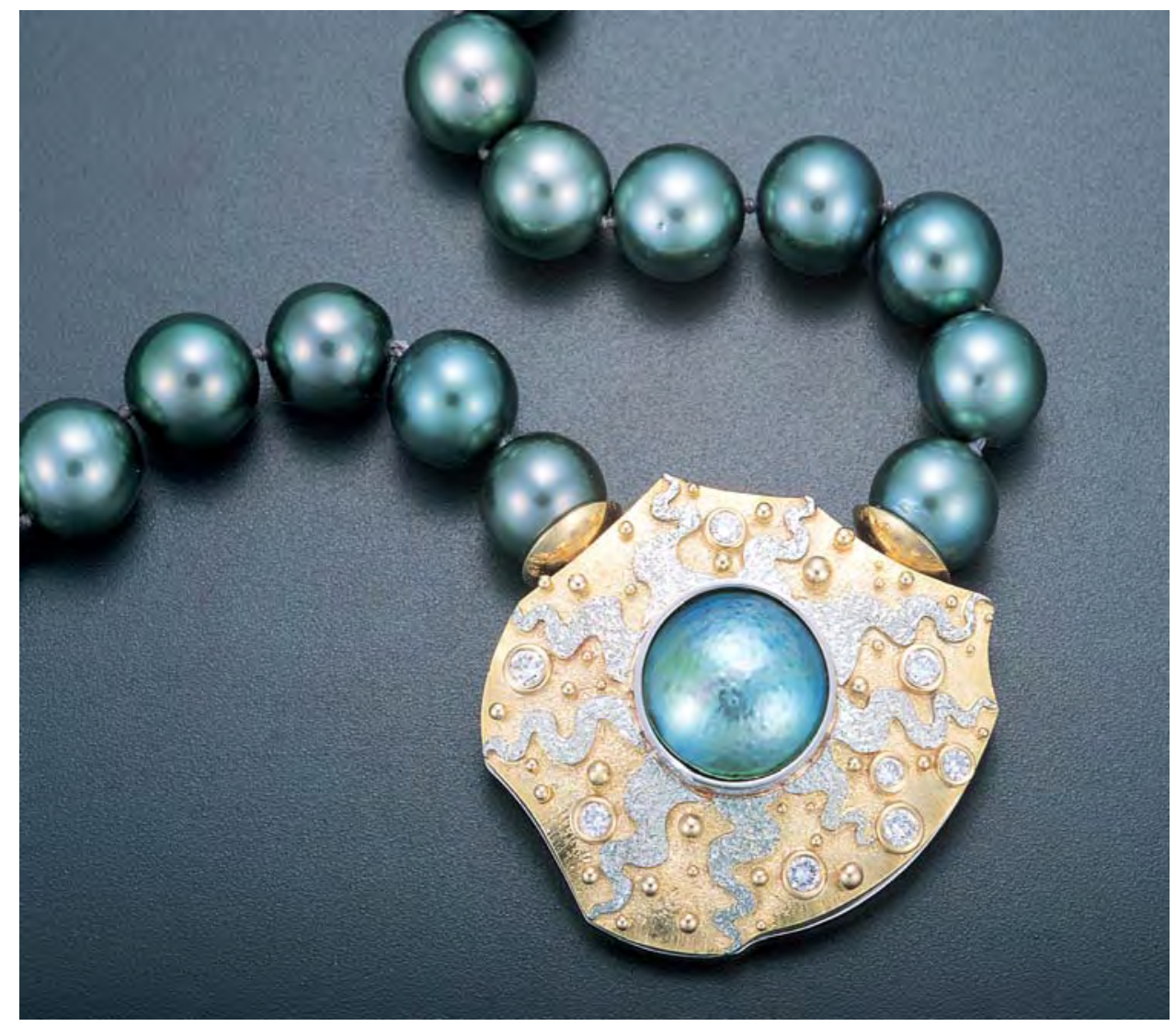

made some remarkable advances in culturing abalone pearls by drilling a hole through the shell to secure the nucleus (Fankboner, 1995; McKenzie, 1996). He has since reported growing blister pearls up to $22 \mathrm{~mm}$ in diameter in Haliotis discus in Japan. However, his attempts at producing whole round pearls were not as successful (Fankboner, 1991). Subsequently, Cho Won-Ho, president of Korea Abalone Pearls in South Korea, began cultivating abalone pearls; in 1991, he projected the successful production of large whole spherical abalone pearls ("Bigger abalone ...," 1991). However, this pioneering effort has been halted, as the company has discontinued operations.

In the mid-1980s, Dr. Peter V. Fankboner, a professor at Simon Fraser University in Burnaby, British Columbia, was the first to produce jewelryquality cultured abalone blister pearls in North America, using the pinto abalone Haliotis kamtschatkana (Fankboner, 1995). Dr. Fankboner has since produced perhaps the world's largest blister pearl, which measures $27 \mathrm{~mm}$ (just over one inch) across the base ("SFU marine biologist claims world record ... ," 1996). He has experimented with producing spherical bead-nucleated pearls, and claims to have cultured a few whole freeformed tissue-nucleated pearls as large as $8 \mathrm{~mm}$ (P. Fankboner, pers. comm., 1998).

Dr. Fankboner also reports that, in addition to his own company (Pacific Pearl Culture Ltd., Burnaby, B.C., Canada), there are three other producers of cultured abalone blister pearls on the west coast of North America, all in California: Jack Joyner of California Abalone Pearls, Santa Barbara; Joe Cavanaugh and Art Seavey of Monterey Abalone Co, Monterey; and Tim Ross of North Coast Sea Farm, Crescent City. Dr. Fankboner and GIA Gem Trade Laboratory (GIA GTL) staff members believe that there is also a producer on the west coast of Baja California, in Mexico, but the name could not be obtained.

Abalone pearl culture has been attempted in many other countries, including Australia, New Zealand, China, South Africa, Mexico, Chile, and Ireland (Fankboner, 1995). According to a 1997 article by Cropp, recent experiments for producing three-quarter blister to round pearls in Hawaii were encouraging. Tasmania entered the field in the early 1990s, when Abalone Pearls Pty. Ltd. first successfully produced blister pearls, and began targeting 


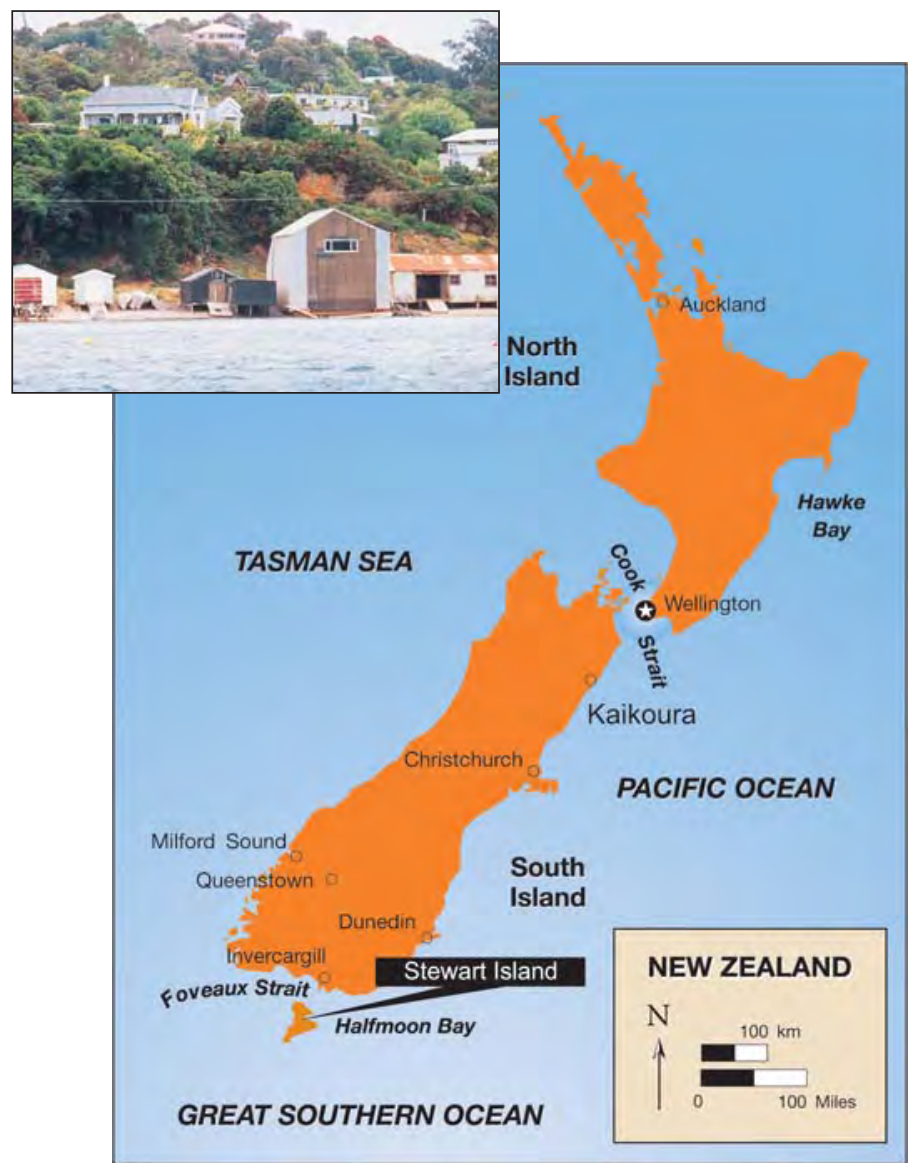

Figure 2. Empress Pearls are cultured primarily on New Zealand's Stewart Island, with a research facility at Kaikoura on the main south island. The inset shows the Stewart Island production facility, which is located at Halfmoon Bay. Photo courtesy of Empress Abalone Ltd.

spherical pearls, in the greenlip abalone Haliotis laevigata (Cropp, 1997). The latter trials, which are nearing completion, have confirmed the formation of a pearl sac, the first stage in the development of these cultured spherical pearls.

Since 1995, Empress Abalone Ltd. of New Zealand has successfully cultured commercial quantities of pearls in the brightly colored $H$. iris, or paua, abalone. Their research and production activities are described below. Another company that uses $H$. iris is Rainbow Pearls, located in New Plymouth, Taranaki, on the west coast of New Zealand's north island. This facility, once solely a commercial abalone hatchery, now produces assembled cultured blister pearls.

\section{BACKGROUND OF THE "EMPRESS PEARL"}

Location and Access. New Zealand is a topographically and climatically diverse country that consists of two main islands and several smaller ones (figure
2). Abalone blister pearls are cultured by Empress Abalone Ltd. at Halfmoon Bay on the northeast side of Stewart Island-a third, smaller island southernmost in New Zealand. This facility (figure 2, inset), which is open for visitors, is accessible from Invercargill, on the main south island, via an approximately one hour ferry ride or a 20 minute flight. Empress Abalone also has a research facility at Kaikoura, a small town on the northeast coast of the main south island, about $180 \mathrm{~km}$ (112 miles) north of Christchurch (McKenzie, 1996).

New Zealand is surrounded by three major bodies of water: the Pacific Ocean to the north and east, the Tasman Sea to the west, and the Great Southern Ocean to the south. The subtropical and subantarctic currents converge at Stewart Island, creating an influx of nutrients and producing a rich and diverse marine environment. At Kaikoura, the continental shelf comes very close to shore, creating another diverse marine environment that benefits from the upwelling of rich nutrients.

Company Structure and Facilities. In 1995, Liz and Michael McKenzie of Goldrush Gem Co., a New Zealand jewelry firm, teamed up with a group of abalone divers from Abalone Producers and Partners to form a new company, Abalone Partners Ltd., on Stewart Island's Halfmoon Bay. This operation is managed by partner Ron Dennis. The McKenzie family also holds 55\% interest in Empress Abalone Ltd., of Christchurch, which has sole marketing rights for the product. The remaining interest is held by 20 shareholders. Recently, Empress Abalone Ltd. has taken over Abalone Partners Ltd., so it is now responsible for both the production and marketing of the cultured blister pearls. They have contracted with Goldrush Gem Co. for all of the postharvest processing.

The abalone are housed onshore in 150 onecubic-meter rubber tanks, each capable of holding 1,000 liters of water and 70-80 abalone (figure 3). There are three full-time employees and up to seven seasonal staff members. During the next three years, the McKenzies plan to build a much larger facility, with a projected capacity of 100,000 abalone, $16 \mathrm{~km}$ (10 miles) north of Kaikoura, in the small town of Maungamanu.

For its research activities, Empress Abalone Ltd. leases space at the George Knox Research Laboratory at Kaikoura (owned by the University of Canterbury in Christchurch). Currently this facility has 25 tanks and two full-time researchers. With 
the help of a government grant, research on all aspects of abalone and pearl cultivation is being conducted in conjunction with the university. This research includes the triggers for nacre production, the effects of feed changes on pearl color, and abalone breeding.

\section{ABALONE BIOLOGY}

Abalone mollusks are a primitive group of marine snails of the class Gastropoda, subclass Prosobranchia, order Archaeogastropoda, family Haliotidae (Howorth, 1978). The largest of all gastropods (Nieson, 1994), they are a type of limpet prized for their delicately flavored meat, iridescent mother-of-pearl, and pearls. There are about 90-100 species worldwide (Haldane, 1992; Fankboner, 1995), but according to Fankboner, less than two dozen reach a size practical for pearl culture.

Abalone have separate sexes and breed by external fertilization. Millions of eggs and clouds of sperm are released into the water and drift about until they unite. Because fertilization is so random, a given animal may successfully breed in nature only once every six or seven years (Haldane, 1992). The fertilized eggs grow into larvae, and then into free-swimming veligers which settle on a hard substrate. The veligers develop into abalone, which grow at a rate of about $15-20 \mathrm{~mm} /$ year. This growth rate is slower than that of other mollusks used for pearl culture, but with farming it increases to about $25 \mathrm{~mm} /$ year. An oval adult shell reaches about $12-14 \mathrm{~cm}$ in length.

Abalone live in clusters from the low tide mark to a depth of about $36 \mathrm{~m}$ (McGraw-Hill, 1987). They feed nocturnally, by scraping algae (i.e., coralline algae as juveniles, and kelp and other seaweed as adults) with their radula, a file-like tongue with rows of chitinous projections (McLean, 1969; Howorth, 1978). A row of open pores along one side of the shell is used for respiration, excretion, and breeding (figure 4). Although abalone are generally hardy, they have no mechanism to coagulate their blood. If an animal sustains a significant cut, it will probably bleed to death (Cox, 1962), or it may die from the lost mobility that results when it muscularly clamps the wound closed (M. McKenzie, pers. comm., 1998). The average life span is about 10 years, but under ideal conditions, abalone can live as long as 40 to 50 years (Howorth, 1978).

$H$. iris, which is found exclusively off the coast of New Zealand, is considered by many to boast the most vividly colored mother-of-pearl of all the abalone species (see, e.g., figure 4). The cause of the rainbow-like hues is discussed by Brown (1985, 1997). According to Liz McKenzie, colder waters, such as those off the south island, favor the formation of highly iridescent and colorful pearl nacre.

\section{GATHERING ABALONE STOCK}

Abalone diving in New Zealand is quota-based with a limited entry; the total quota does not exceed 908 tonne/year. (There are approximately 2,000 adult abalone, each at least $12.5 \mathrm{~cm}$ long, in a tonne.) Empress Abalone Ltd. leased 4.5 tonne in quotas from other divers last year; they prefer to use their own divers to assure care and quality.

The abalone are collected offshore from the Kaikoura and Stewart Island facilities. The divers choose predominantly rocky locations to avoid sand contamination, which can cause problems during cultured pearl growth. Each quota season begins October 1 and continues all year. However, diving conditions are most favorable from October through March, after which most activity ends. Because the use of compressed-air diving tanks is prohibited by law, snorkelers collect the abalone (figure 5) from

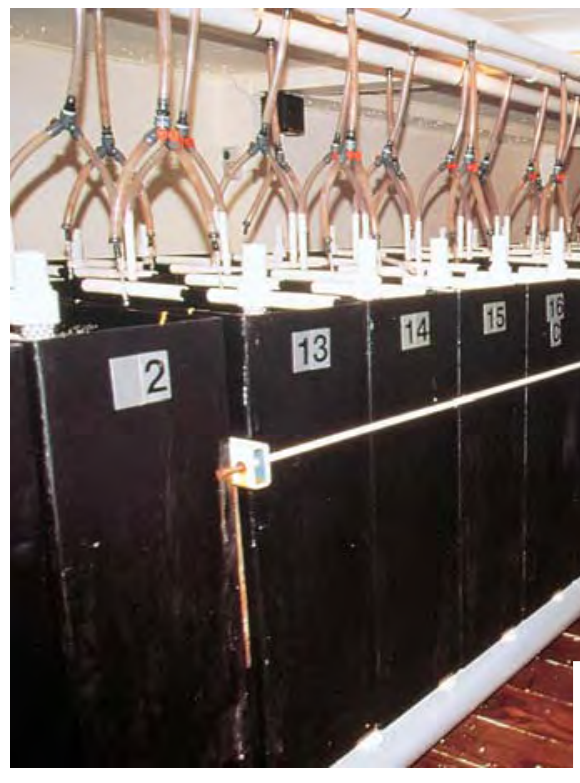

Figure 3. The Stewart Island facility has 150 rubber tanks, each containing 70-80 nucleated abalone (inset). Filtered and aerated water is maintained at $12^{\circ}-15^{\circ} \mathrm{C}$ during the nacregrowth stage. Photos courtesy of Empress Abalone Ltd.

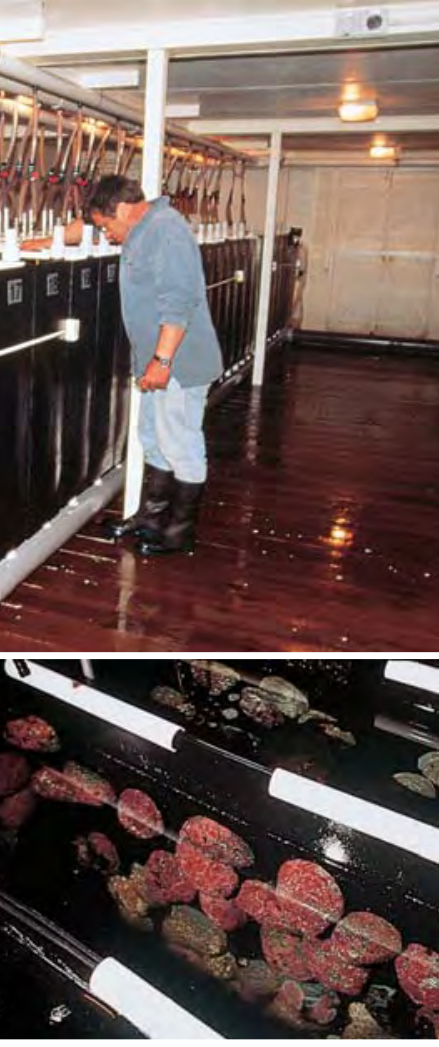




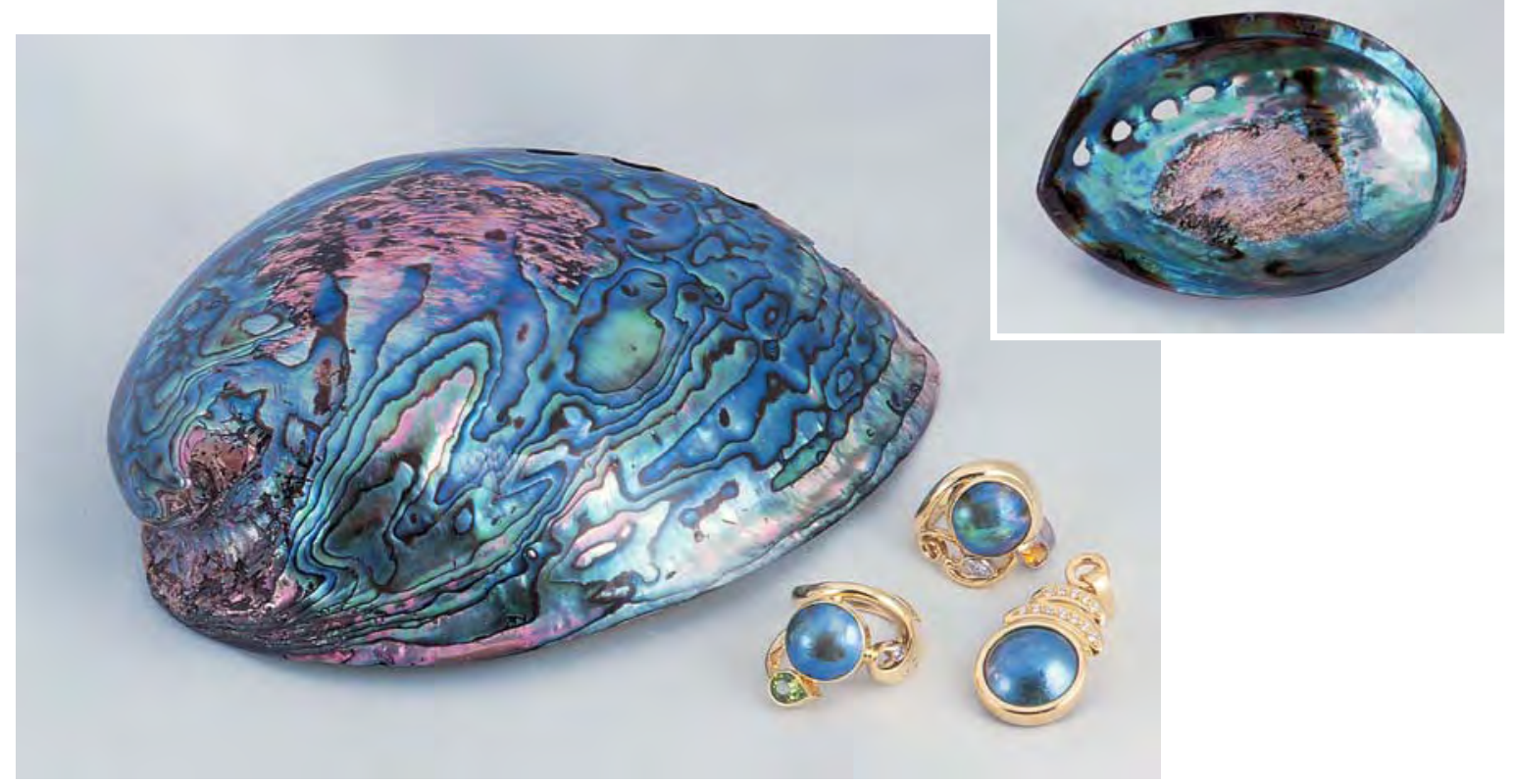

Figure 4. Haliotis iris, also known as paua abalone, creates what may be the most iridescent and vividly colored mother-of-pearl and pearl nacre of its genus. Colorful patterns are seen on the exterior of this shell, which has been polished and lacquered. The interior (inset, also lacquered) shows vibrant colors as well; the abalone uses the row of holes for respiration, excretion, and breeding. The nucleus is inserted into an area near the apex of the shell (on the right side of the inset photo), where it is most difficult for the abalone to dislodge it. The cultured and assembled abalone blister pearls in the rings and pendant range from $12.5 \mathrm{~mm}$ to $15.8 \mathrm{~mm}$. The rings were designed and manufactured by Ian Henderson,

Dunedin, New Zealand; the pendant was designed and manufactured by Goldrush Gem Co.,

Christchurch, New Zealand; photos by Maha DeMaggio.

the low-tide mark down to about $9 \mathrm{~m}$ (30 feet). About 100-200 kg of abalone are gathered during a typical diving excursion (about two hours).

Because of their "hemophiliac" nature, abalone must be collected with care. Traditionally, a type of pry bar called an abalone iron has been used; however, Empress Abalone's divers have found that a triangular masonry trowel presents less risk of injury to the animals. The abalone are gathered by inserting this tool between the animal's muscular foot and the rocky substrate. The abalone collected are at least five years old; much older abalone, which have thicker shells and grow more slowly than the young ones, are not as desirable for cultured pearl production. The abalone are assessed by eye before they are removed from their environment, and any unsuitable specimens are returned unharmed if possible.

Presently, Empress Abalone is using only wild stock for pearl culturing, but an additional three tonne of abalone are being grown at the Kaikoura facility as the company strives to shift to cultivated stock by late 1999. Natural abalone stocks in New Zealand were once in danger of depletion, but the government quota system has prevented this.
Although the population is sustained only by natural breeding, the New Zealand marine environment is free of the diseases and pests that deplete abalone populations in other locations. The withering-foot disease that infests the American abalone is absent, as are parasitic nematodes, polychetes, boring clams, snails, and sponges that are prevalent in other locations. There are a few predators such as seals, but their impact is minimal.

\section{CULTURING ABALONE BLISTER PEARLS}

Nuclei Implantation. Hemispherical plastic forms, used in the culture of traditional blister pearls (Ward, 1998), are also used in abalone. The McKenzies use economical material formed with casein, a by-product from a milk factory. The abalone are very sensitive to the shape of these nuclei. Because of the highly concave shape of their shell, they resist depositing nacre on a convex surface such as a high-domed bead. Better nacre deposition is achieved with flatter nuclei profiles. Also, pointed outlines such as pear shapes and hearts are generally uneconomical because the points often pierce the flesh of the abalone and cause it to bleed to death. Although 8-16 mm hemispherical nuclei 
are the most favorable for producing cultured blister pearls, oval profiles often work, and pear-shaped profiles are being modified to achieve greater success.

With their strong musculature, abalone can easily eject any foreign body that comes between the mantle and the shell. To combat this, the nucleus is inserted (along with a piece of mantle tissue to generate nacre deposition) into an area near the apex or whorl of the shell (again, see figure 4), where it is most difficult for the abalone to dislodge it. The McKenzies report that their implantation technique is completely different from that used by Peter Fankboner on the North American coast (see, e.g., Fankboner, 1994). Although the exact methods are proprietary, the McKenzies indicate that they use tools that are specially designed and manufactured for the purpose, and that their technique is less invasive than some methods used by other culturers, as it does not involve cutting.

Nuclei implantation, or "seeding," takes approximately three minutes for each abalone. Although the nuclei can be implanted throughout the year, seeding is typically done from October to the beginning of December (middle to late spring in New Zealand), after the spawning season, when the gonad is smallest and access is easiest. A single nucleus is usually implanted into each animal. If two nuclei are used, the nacre commonly forms a bridge between them.

Cultured Blister Pearl Growth. Although abalone are hardy in their environment, they do not tolerate chemicals and do not like to be handled. If picked up, they will refuse to eat or produce nacre. To get over the shock of nucleation, the abalone are placed in recovery tanks for two weeks before they are transferred to permanent tanks (again, see figure 3). They remain there undisturbed until harvest.

Three basic complications can prevent successful cultured pearl growth: (1) the abalone dies, usually due to bleeding; (2) the nacre is deposited unevenly or incompletely; and (3) the nucleus causes a cyst to form. The mortality rate from abalone collection and blister pearl nucleation is relatively low (5\%), but this increases (to $30 \%$ ) when "free" nuclei (to produce whole pearls) are implanted. If the abalone survives the culturing process, the blister nucleus may be "ignored" rather than expelled; instead of being covered with nacre, all or part may be covered with conchiolin only. Sometimes during nucleation, sand irritation will cause the implanted bead to induce an infection instead of stimulating

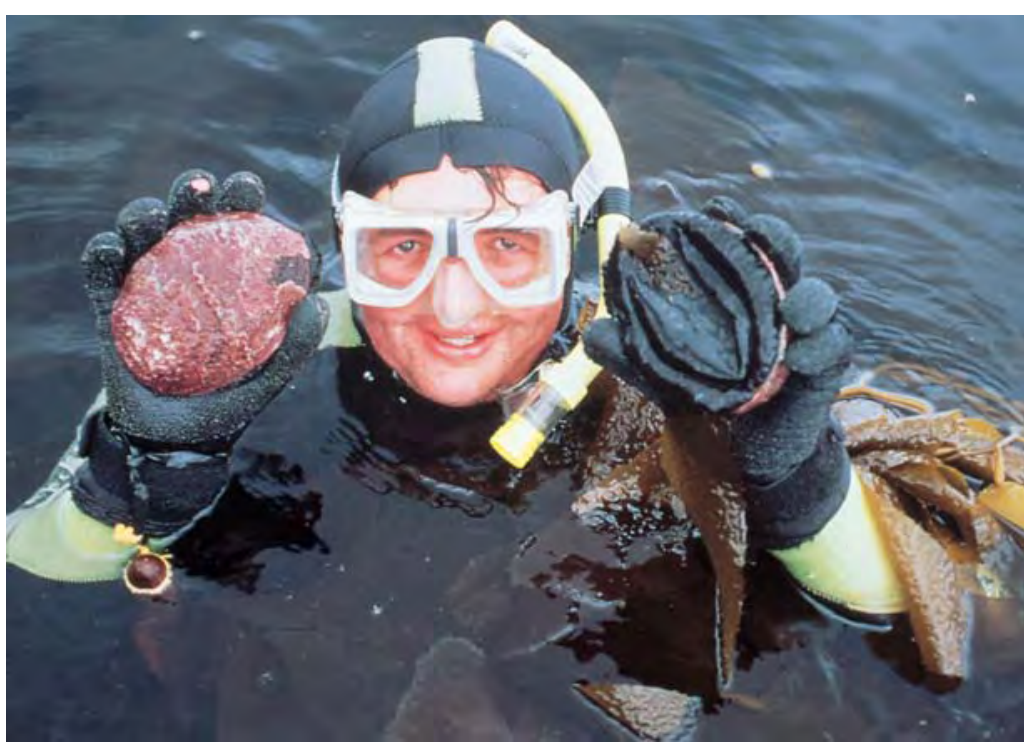

Figure 5. Divers collect wild abalone from rocky locations at depths reaching $9 \mathrm{~m}$ (30 feet). During each approximately two-hour excursion, the divers typically retrieve 100-200 kg of abalone. Photo courtesy of Empress Abalone Ltd.

nacre growth. The result is a festering cyst rather than a cultured pearl.

$H$. iris need a minimum water temperature of $12^{\circ}-15^{\circ} \mathrm{C}\left(54^{\circ}-59^{\circ} \mathrm{F}\right)$ to stimulate nacre growth. However, if the water becomes too warm (e.g., approaching $18^{\circ} \mathrm{C}$ or $64^{\circ} \mathrm{F}$ ), the abalone will stop producing nacre and may even seek lower temperatures by crawling out of the tanks. In the wild, nacre is deposited rapidly in the summer and specifically to the irritant site. As the temperature drops, nacre deposition slows. Conchiolin is laid in the winter, in waters as cold as $9^{\circ} \mathrm{C}\left(48^{\circ} \mathrm{F}\right)$. Conchiolin and other organic compounds (the mixture of which will be referred to here as conchiolin) are important, as they provide the dark background against which the colors in the overlying nacre reflect.

Cultured blister pearls up to $12 \mathrm{~mm}$ in diameter (starting with $10.5-11 \mathrm{~mm}$ nuclei) are formed in two seasons (18 months). Larger blister pearls, 12-18 mm, take three seasons (approximately 24 to 30 months) to form.

Growth Environment. The onshore holding tanks contain clear natural saltwater that is continuously replenished by water piped in from $100 \mathrm{~m}$ offshore. The water is filtered to minimize contamination by sand, and is maintained at a temperature of $12^{\circ}-15^{\circ} \mathrm{C}\left(54^{\circ}-59^{\circ} \mathrm{F}\right)$ during the nacre-growth phase. The water is aerated to discourage the growth of undesirable algae. The environment in the tanks is 
strictly monitored to ensure the health of the abalone, as well as maximize the growth rate and nacre thickness of the cultured pearls. By maintaining specific water temperatures that are varied throughout the growing process, the operators can simulate optimal growth seasons. They also keep the facility in darkness, so that feeding is always stimulated.

Feeding. Abalone require very little care. Once the environment is established and the nuclei implanted, they need only to be fed while the cultured blister pearls grow. No nutrients or artificial feeds are added to the water; the captive abalone feed exclusively on kelp and other algae collected from the Great Southern Ocean (figure 6). The McKenzies have discovered that the brilliant colors of the cultured pearls are somewhat dependent on the type of feed available to the abalone. The alga species Gracilaria chilensis has been linked to production of the most desirable purple, blue, and green hues. For this reason, the abalone are fed approximately $50 \%$ G. chilensis and a $50 \%$ combination of three other native algae-Durvillea $s p$, Macrocystis sp, and Laminaria sp-that varies seasonally. Approximately $300 \mathrm{~kg}$ of algae per day are required for two tonne of abalone.

\section{HARVESTING AND PRODUCTION}

Although the cultured blister pearls were first harvested twice annually, they are now harvested con-

Figure 6. Kelp is collected from the Great Southern Ocean every three to four days to replenish the abalone diet. The $\mathrm{H}$. iris eat an average of $7 \%$ of their body weight daily; approximately $300 \mathrm{~kg}$ of algae per day are required to feed two tonne of abalone. Photo courtesy of Empress Abalone Ltd.

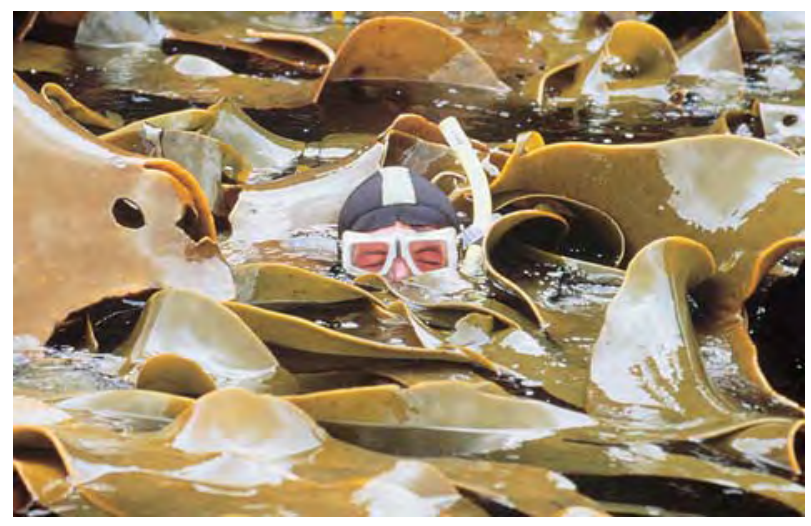

tinuously from the end of July through March. The later harvest allows thicker nacre deposition on larger nuclei. Whereas some other mollusks are implanted three or four times, $H$. iris are shucked (the shells removed; figure 7) at the first harvest because the cultured blister pearls must be cut from the shell. Both shells and meat are important byproducts of the pearl harvest. Most of the meat is exported to Hong Kong. The shell is sought in jewelry and craft manufacturing for its iridescence and vibrant colors.

The results of cultured pearl seeding and growth are unpredictable. Only 25\% of the animals nucleated for the pilot harvest (in 1995) yielded marketable cultured blister pearls. One year later, the success rate was up to $50 \%$ as a result of greater knowledge and improved techniques. Currently, there is an approximately $60 \%-70 \%$ average success rate for obtaining commercially marketable cultured blister pearls from the implanted abalone.

In addition to research harvests, there has been one small pilot harvest and two larger commercial harvests to date. A third was under way at the time of this writing. The first seeding was conducted in the spring of 1993 by Abalone Producers and Partners. This led to the pilot harvest in 1995, when Empress Abalone Ltd. merged with the divers. That harvest yielded approximately 1,100 jewelry-quality cultured blister pearls. The first commercial harvest of 10,000 implanted abalone took place during October and November of 1997, yielding approximately 6,000 cultured blister pearls of good to excellent quality. Another 2,000 abalone were harvested from March through April of 1998, yielding about 1,800 marketable pearls; the high success of this harvest was attributed to the smaller sizes of the nuclei. The third commercial harvest produced 2,000 marketable cultured blister pearls during September 1998, and another 2,000 were expected by mid-October. By the end of March 1999, the McKenzies expect to have harvested a total of 15,000 jewelry-quality cultured blister pearls for this growth period.

Rarely, either a natural pearl or a "keshi" is found during the harvest. Natural pearls may form due to suspended solids, the invasion of a flatworm, or other irritant that is brought in on the seaweed. A by-product of the culturing process, a keshi may form around the implanted tissue that has separated from the nucleus, or as a result of the introduction of another irritant during nucleation (Farn, 1986). 


\section{PROCESSING THE CULTURED BLISTER PEARLS}

Once the abalone are harvested, the cultured blister pearls are cut from the shell with a diamond saw (figure 8), and the rough shell is parted from the blister with a scalpel; the nucleus is then removed, and the dome washed out. The McKenzies report that the interior surface of the dome is not worked or treated in any way. With the shell flange still in place, a blue polymer is poured into the inverted dome. The colored polymer camouflages any cracks that may form in the dome if damaged during wear, as well as any thin or transparent areas. A backing is fashioned from the mother-of-pearl of $H$. iris. If the surface of this backing is uneven, an opaque medium-gray polymer is applied to level it before it is attached to the dome. A transparent colorless glue is used to bind the backing to the dome. In all, an assembled cultured blister pearl contains a total of three or four layers, in addition to the nacre (figure 9). The assembly process may be compared to that described by Crowningshield (1982) and Taburiaux (1985) for mabé pearls, where a bead insert is used.

After the layers are assembled, the outline is rounded with a grinder. An attempt is made to bring the outline as close as possible to a calibrated size for ease of setting in jewelry. The dome is then polished with a soft cotton buffing wheel and jeweler's rouge to remove organic compounds. Polishing also imparts a high luster to the surface and optimizes the color. Once assembly and buffing are complete, the cultured blister pearls are cleaned for 20-30 seconds in a warm ammonia solution in an ultrasonic cleaner. This also reveals any cracks that formed during processing. Pearls with significant cracks are rejected.

The McKenzies claim that no coating, wax, or oil is applied to the outer nacre surface, that the ability to achieve a high luster and the transparency of the surface are inherent to the nacre.

\section{IDENTIFYING CHARACTERISTICS}

Materials. Twenty-two cultured blister pearl samples were obtained for examination. All of the blisters were round in outline, and four samples were sawn in half. Eighteen specimens ranged in size from $9.82-9.98 \times 3.35 \mathrm{~mm}$ to $19.02-19.39 \times 7.25$ $\mathrm{mm}$. (According to the McKenzies, the cultured abalone blister pearls range from 9 to $20 \mathrm{~mm}$ in diameter; they average $9-13 \mathrm{~mm}$.) The other four

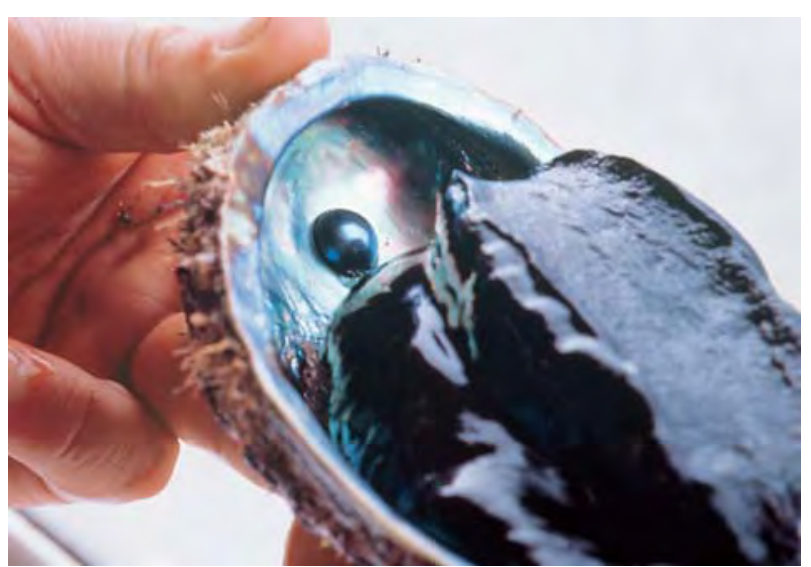

Figure 7. During the harvest, the abalone meat is removed from the shell by hand, or "shucked." This abalone contains a $14 \mathrm{~mm}$ cultured blister pearl. Courtesy of Empress Abalone Ltd.

samples could not be similarly measured since they were still attached to part of the shell.

The McKenzies provided 15 of the specimens. Although they stated that most of the samples had flaws that would preclude their use in jewelry, they were valuable for observing the ranges of color, luster, surface blemishes, and nacre characteristics. Seven came from their first commercial harvest (figure 10). The McKenzies advised that since these samples were removed approximately nine months

Figure 8. The cultured blister pearls are sawn from the shell with a diamond blade. After trimming (inset), the blisters are ready to be processed. Photos courtesy of Empress Abalone Ltd.

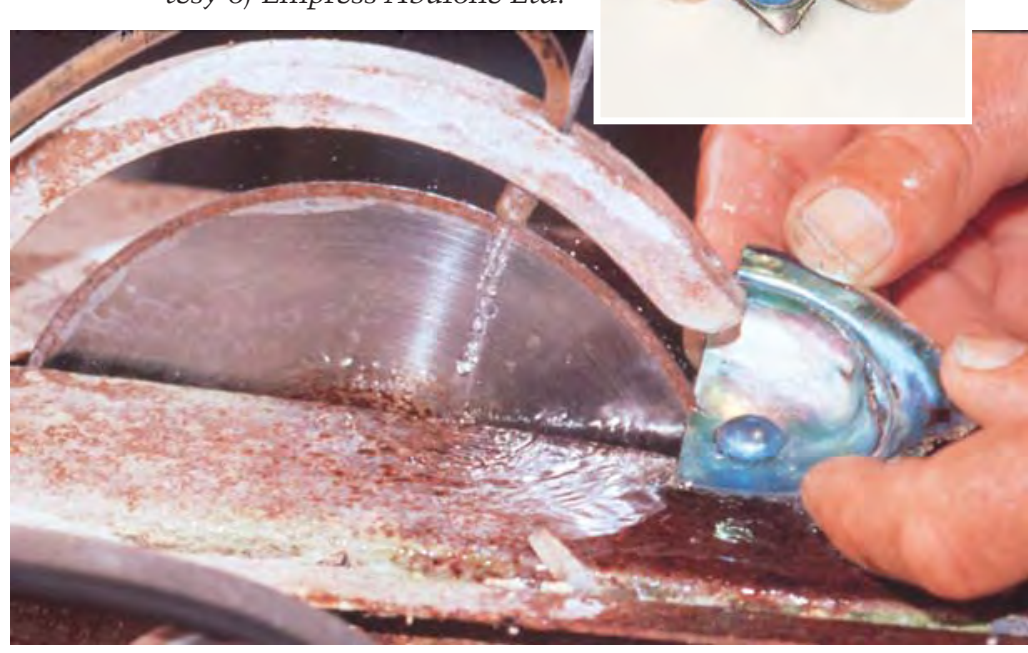




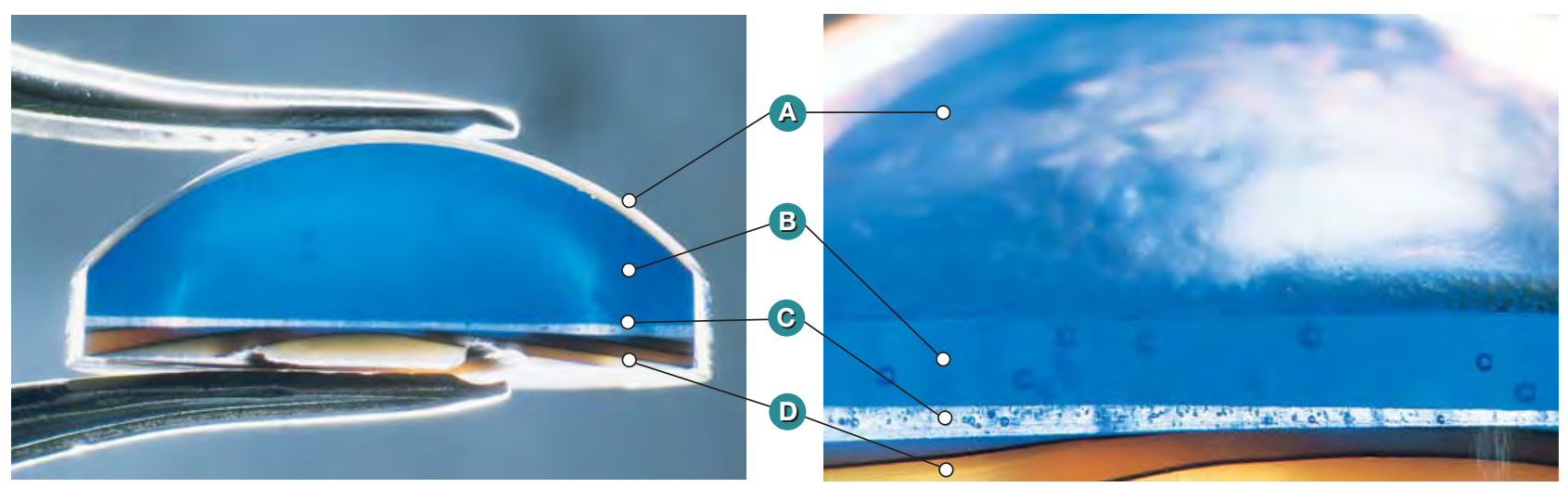

Figure 9. These are two views of one half of an assembled cultured abalone blister pearl. On the left is a cross-section, and on the right is a close-up view along the edge. There are four layers: (A) blister pearl dome (nacre-0.20 $\mathrm{mm}$ thick at the crown and 0.10-0.15 $\mathrm{mm}$ thick at the base), (B) blue polymer layer, (C) colorless glue, and (D) shell backing. An assemblage with an exaggerated thickness of blue polymer was chosen for purposes of illustration; note the bubbles in the polymer and glue layers. Sample courtesy of Empress

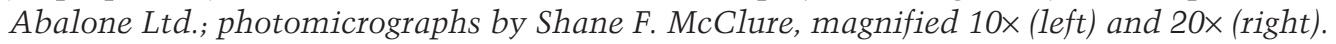

early, as test samples for the harvest, the nacre was thinner than the full-term product. They also noted that four of the seven would be considered rejects by Empress Abalone Ltd., since two had significant cracks and two had noticeably transparent areas.

Figure 10. These seven study samples were from Empress Abalone Ltd.'s first commercial harvest. They ranged from $14.24-14.57 \times 4.74 \mathrm{~mm}$ to $19.02-19.39 \times 7.25 \mathrm{~mm}$. As test samples, they were removed about nine months before the rest of the harvest, and were considered rejects (i.e., not commercial quality) by Empress Abalone Ltd. Conchiolin blemishes appear as dark brown or black spots, patches of speckles, or bands. (Note that the dark area on the front of each sample is a reflection of the photographic equipment.) Several of the samples have an "orange-peel" effect. Photo by Maha DeMaggio.

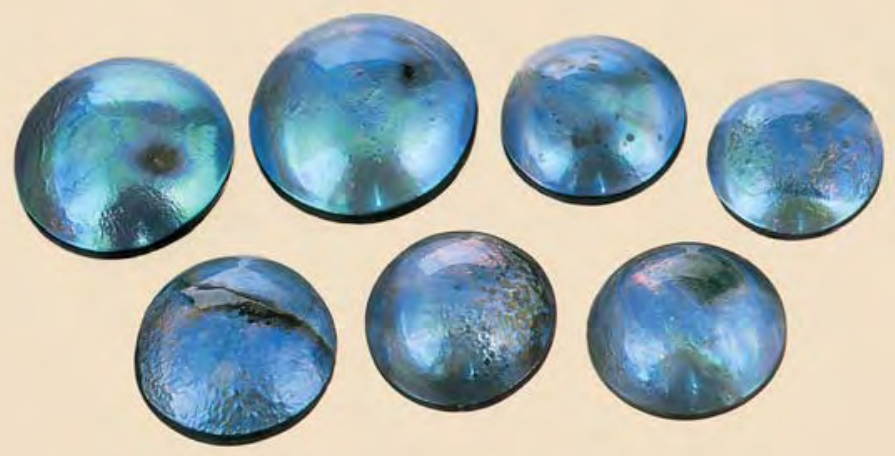

In addition to these seven samples, the McKenzies provided two unpolished samples that were still attached to the shell, with the hemispherical bead nuclei intact (figure 11). They also supplied two samples that had been cut from the shell and partially polished, but were left open in the back with the shell flange still attached. They filled one of these, their lowest-quality product, with their standard blue polymer (again, see figure 11). At the author's request, they filled the second blister with blue polymer on one side of the dome and colorless polymer on the other; this sample was then sawn in half so effects of the polymers on the color of the cultured blister pearl could be compared (figure 12). Also supplied-for cross-section observation and measurement of nacre thickness - were three half-samples that had been processed and assembled before they were sawn (again, see figure 9a).

Three unmounted samples were provided by U.S. distributor Betty Sue King of King's Ransom, Sausalito California, as products representative of those on the market in 1998 (figure 13). Five samples set in jewelry were also examined, four of which were provided by designer/jeweler Ian Henderson of Dunedin, New Zealand (see the photo on the cover of this issue) and one that was supplied by the McKenzies (again, see figure 4).

Methods. The colors were observed using a Gretag MacBeth Judge II light box with a neutral gray background and two 20 -watt $6,500 \mathrm{~K}$ color temperature bulbs that simulate average daylight. Refractive indices were determined on all samples by the spot method using a standard GIA GEM Instruments 
gemological refractometer. No weights or densities were measured because of the assembled nature of the pieces. Ultraviolet fluorescence was observed in a dark room using a viewing box equipped with a GIA GEM Instruments long-wave $(366 \mathrm{~nm})$ and short-wave $(254 \mathrm{~nm})$ UV lamp. All samples were examined with a Gemolite Mark VII Stereo Star Zoom binocular microscope. A Cuda Products variable-intensity pinpoint fiber-optic light source was used for observations both with and without magnification. A GIA GEM Instruments table gauge was used to measure nacre thickness on three sawn samples.

Qualitative chemical analysis of three samples was performed with a Tracor X-ray Spectrace 5000 energy-dispersive X-ray fluorescence (EDXRF) spectrometer. One analysis was performed on the nacre dome of a cultured blister pearl assemblage, one was performed on a piece of unprocessed abalone shell, and one spectrum was taken of the blue polymer filler. An X-ray powder diffraction pattern was obtained with a Debye-Scherrer camera mounted on a Siemens Kristalloflex diffractometer, to determine the composition of a shallow surface scraping of the nacre on one assemblage. An Edsyn 951SX Loner soldering station was used at the maximum setting $\left(427^{\circ} \mathrm{C}\right.$, or $\left.800^{\circ} \mathrm{F}\right)$ as a thermal reaction tester for polymer coating on one lustrous sample with transparent nacre. Attempts to detect polymer coatings were also made using a Nicolet Magna-IR 550 Fourier-transform infrared (FTIR) spectrometer; a

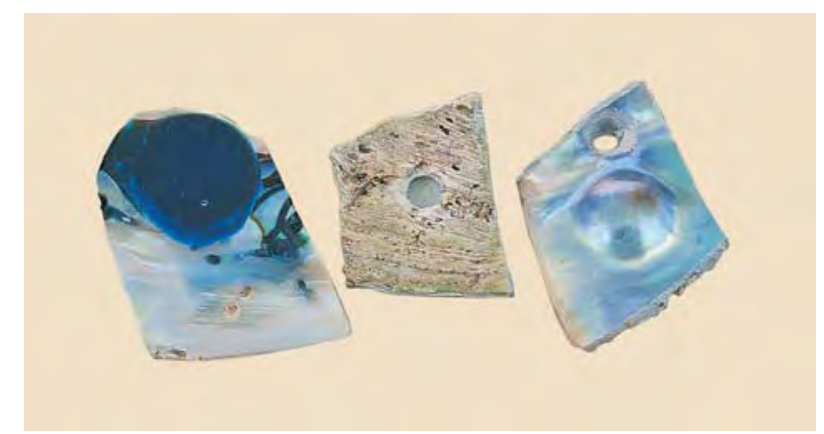

Figure 11. The two unprocessed, unpolished samples on the right were still in the shell with the hemispherical bead nuclei intact (note that the intensity of the colors is similar to the assembled product). The center sample is positioned facedown, to show the rough surface of the outer shell. The sample on the left (also face-down) had been separated from the outer shell, filled with blue polymer, and partially polished. Courtesy of Empress Abalone Ltd.; photo by Maha DeMaggio.

spectrum was obtained of a pelletized shallow surface scraping from the nacre of one sample using the transmission mode. An FTIR attachment for obtaining diffuse reflectance spectra and a Renishaw system 2000 Raman microspectrometer were also used to examine the surface of one sample for polymer coatings.

Some recent coatings are the result of polishing with compounds that leave a very thin film on the surface. Detection of these films, which may be only fractions to a few microns thick, requires equipment such as the scanning electron micro-

Figure 12. One side of this cultured abalone blister pearl was filled with blue polymer, and the other side was filled with colorless polymer (left). The sawn surface allowed observation of two thin conchiolin layers beneath the nacre (which gave a brownish appearance to the colorless polymer). These layers were sufficient to minimize the effect of the blue polymer on the color of the pearl: When the two sides were viewed face-up (right), there was no discernible color difference between them. Sample courtesy of Empress Abalone Ltd.; photos by Maha DeMaggio.
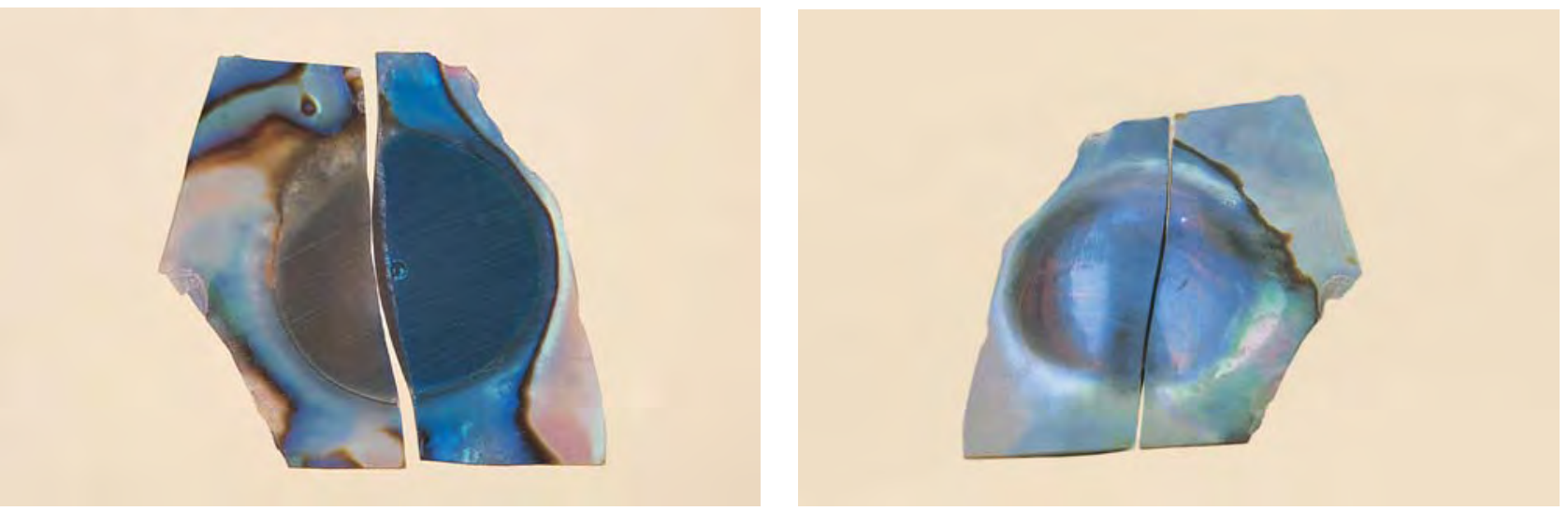


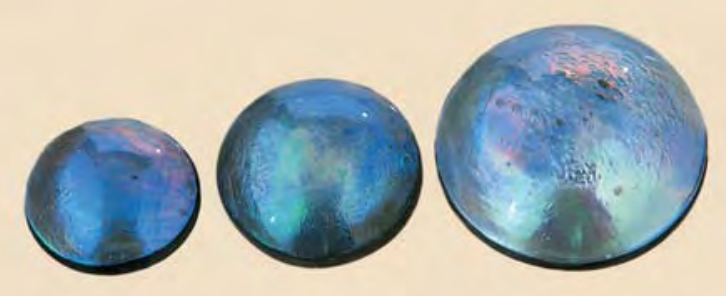

Figure 13. These three cultured and assembled abalone blister pearls are representative of those commercially marketed in 1998. The samples measured from 9.82-9.98 × $3.35 \mathrm{~mm}$ to $15.30-15.46 \times$ $5.33 \mathrm{~mm}$. Empress Abalone Ltd. had graded them (from left to right) as "Gem," "A," and "B." Notice the "orange-peel" effect on the "B" grade product. Samples courtesy of Betty Sue King, King's Ransom; photo by Maha DeMaggio.

scope. Seven cross-section images were taken from freshly broken edges of a cultured blister pearl assemblage using an ElectroScan Model E3 environmental scanning electron microscope (ESEM). For comparison, three images were taken of a fresh abalone shell fracture. The images ranged in magnification from approximately $600 \times$ to $6000 \times$.

Durability testing included the use of standard Moh's hardness points to determine the resistance of the surface of one sample to scratching. A fade test was conducted with an Oriel model 81150 solar simulator with a 300-watt xenon light source; the output emission approximates the daylight spectrum at approximately two times normal intensity. One half of a cultured blister pearl was subjected to 4.5 hours in the simulator, while the other half was kept in a darkened room to be used for comparison.

\section{RESULTS}

Color. The McKenzies state that the main bodycolors of their samples range from green through "peacock" green-blue to deep "azure" blue, and rarely, a deep violetish blue. Secondary colors and overtones include pink, purplish pink, purple, yellow, and orange. They report that the colors are typically more intense in the smaller cultured blister pearls than the larger ones. The colors in the study samples were vivid, and strong iridescence caused them to appear to shift or roll across the surface. The main bodycolors of these samples were combinations of blue, green, purple, and pink. Blue and then green were the most prevalent hues and dominated the coloration of most samples. Two samples were predominantly deep "azure" blue; one sample was dominated by purple. Others showed purple or purplish pink to pink areas. Two samples were a combination of blue and gray. Purple, pink, yellow, blue, and green overtones were observed. Although some of the smaller samples were more blue and some larger samples contained more green, no relationship could be drawn between color and size. All samples appeared equal in intensity.

Luster. The McKenzies report that the luster of their product ranges from satiny to vitreous; the reflections appear diffuse to almost mirror-like. The lusters of the polished study samples ranged from high to extremely high, as compared to other kinds of pearls, and the luster and reflection descriptions concurred with those of the McKenzies. The light reflecting off the conchiolin layers imparted an almost metallic apppearance to the pieces. The surfaces of the unpolished samples had very thin layers of organic material and whitish deposits that dulled the luster; these are removed during polishing.

Surface Characteristics. Examination of the surfaces with $10 \times$ magnification revealed several features. One sample had a large dark brown spot of conchiolin but otherwise was smooth and highly lustrous. Six other samples had smaller isolated conchiolin spots or several dark speckles; another three each had a dark brown to black band of conchiolin (figure 10).

Observation with $10 \times$ magnification also revealed cracks in nine samples. These were usually quite thin and not apparent with the unaided eye: One cultured blister pearl had a small patch of crazing near the edge of the base, one had a network of cracks in an isolated patch, and six had single hairline fractures. Two of the thin cracks in the lowerquality materials had microscopic evidence of polymer, which typically seeps through pre-existing cracks and exposes them during processing, a benefit for quality control. One sample, a reject from the early harvest, had a large crack across the crown and a large gap at the edge of the base.

Features with the appearance of small bumps and welts gave several samples an "orange-peel" effect (figures 10, 13, and 14). These characteristics were most often seen under the surface of the nacre at the interface with the conchiolin layer, and are typical of abalone pearls. Also seen with magnification (and typical of abalone pearls) was the cellular structure of the nacre (see photo in Kammerling and 
Fryer, 1994) and nacre structures that appeared somewhat botryoidal. On four samples, the nacre displayed a milky haziness, and two partially polished samples had polishing marks; both of these characteristics were only visible with $10 \times$ magnification. The surfaces of two unpolished domes that were still attached to the shell had thin layers of organic material.

Refractive Indices. Observation of refractive indices revealed a birefringence blink on all samples, and indistinct to fair spot readings. Alpha varied from 1.50 to 1.52 for the 22 samples; this was close to the value for aragonite, 1.530. Gamma was more difficult to see, and only two samples, which had high polish, gave clear readings of 1.68 - close to the corresponding aragonite value of 1.685 . The other samples gave indistinct gamma readings that were not reliable.

UV Fluorescence. When exposed to long-wave UV radiation, 13 samples showed a mottled and chalky medium greenish yellow fluorescence, eight samples had weak fluorescence, and one had very weak fluorescence. The same, although weaker, reaction was seen with short-wave UV. These characteristics are consistent with those reported for abalone pearls by Brown (1985).

Assemblage Characteristics. The individual layers of each assemblage could be discerned with magnification (again, see figure 9). The layers observed were consistent with those described in the processing section. Only two of the samples examined by the author had the extra layer of gray polymer that was used to level the surface of the backing before it was applied.

Nacre and Conchiolin. The McKenzies report that the nacre thickness of Empress Pearls typically ranges from 0.15 to $0.25 \mathrm{~mm}$ on the crown of a blister dome, and up to $2 \mathrm{~mm}$ around the base where it attaches to the shell. The nacre thicknesses of the three sawn assemblages ranged from $0.13 \mathrm{~mm}$ to $0.40 \mathrm{~mm}$ at the apex of the crowns. The dome bases were measured on each side of the sawn face and ranged from $0.10-0.15 \mathrm{~mm}$ (again, see figure 9) to $0.30-0.50 \mathrm{~mm}$. The thickest nacre at the point of attachment to the shells had been ground away during fashioning. The blister that had one half of the dome filled with blue polymer and the other half filled with colorless polymer still had the shell flange; the nacre measured $0.20-0.25 \mathrm{~mm}$ at the apex of the crown and $0.80-0.90 \mathrm{~mm}$ at the point of attachment to the shell.

When the nacre was examined with an intense fiber-optic light, and without magnification, five of the 22 samples showed noticeably thin or translucent areas that easily transmitted light. Two of these five were early-harvest test samples (both rejects); one, also a reject, had been sawn in half; and two were jewelry-quality samples. One of these latter samples had a transparent patch near the girdle through which the dark polymer could be seen with transmitted and reflected light (figure 14), although it would probably not detract from the face-up appearance if bezel-set in a mounting.

Seven additional samples showed translucent areas of varying size and intensity. Also with the fiber-optic light, numerous gas bubbles in the polymer were eye-visible through the nacre of five samples (figure 15). Except for the one jewelry-quality pearl mentioned above, none of the marketable samples had nacre deficiencies that could be discerned with the unaided eye in reflected light (the normal situation in which pearls are viewed).

The three samples that had been sawn in half were examined without magnification and with an intense fiber-optic light directed at the domes. The visibility through the nacre of both the colored polymer and the associated gas bubbles was dependent on the presence and thickness of conchiolin layer(s) rather than on the thickness of the nacre. A

Figure 14. This assembled cultured abalone blister pearl has a transparent patch of nacre near the edge of the base, through which the dark polymer can be seen. Notice, too, the "orange-peel" effect visible with magnification. Sample courtesy of Betty Sue King, King's Ransom; photomicrograph by Shane F. McClure, magnified 12x.

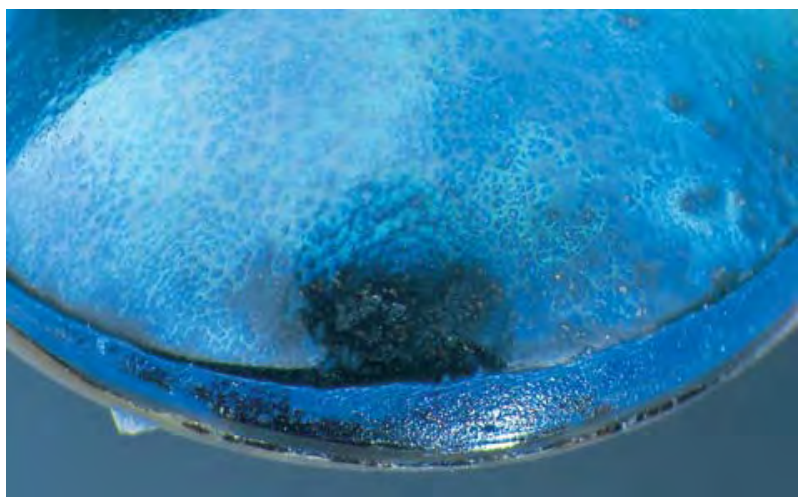


single thick conchiolin layer or two thinner conchiolin layers effectively blocked the passage of light from the nacre into the polymer. The dark tone of the polymer also helped block the transmission of light. This was evident in the cultured blister pearl that had been half-filled with blue polymer and halffilled with colorless polymer. This sample contained two thin layers of conchiolin, and strong fiber-optic light did not pass through the half with the blue polymer, but it internally illuminated the half with the colorless polymer. Samples that had no conchiolin layer, or only a single thin conchiolin layer, allowed the transmission of light into the colored polymer, which then glowed through the nacre. This illuminated polymer was visible only with intense fiber-optic light. Although bright overhead lighting caused subtle illumination of the colored polymer in samples with very thin or no conchiolin, moderate overhead lighting did not cause such reactions. The gas bubbles were not visible under normal viewing conditions. It is interesting to note that the polymer appeared green when viewed through the nacre of some assemblages, even though the same type of blue polymer appeared to have been used for all the samples (again, see figure 15).

Testing for Coatings and Dyes. The surfaces of all the domes were examined with magnification for evidence of coatings and dyes, and four were subjected to different advanced testing methods. No coatings or dyes were detected, although some extremely thin polymer films (a few microns or less) and organic dyes cannot be detected by these techniques. The physical properties inherent to abalone nacre, combined with the high luster from polishing, gave a transparent appearance to the surfaces of these samples that mimicked a colorless coating. With $10 \times$ magnification, the structure of the nacre was consistent with that of natural abalone pearls seen in GIA GTL, and there was no evidence of dye concentrations.

Heating with a thermal reaction tester did not produce any odors or melting characteristic of polymer coatings. In fact, when heated to the point of burning, the surface sloughed off in platy flakes, a reaction that, in the experience of staff members at GIA GTL, is typical of nacre. When a drop of $37 \%$ $\mathrm{HCl}$ solution was placed on the surface of a nacre dome and studied with magnification, it was observed to effervesce strongly and immediately. A noticeably thick polymer coating would be expected to block this immediate reaction.

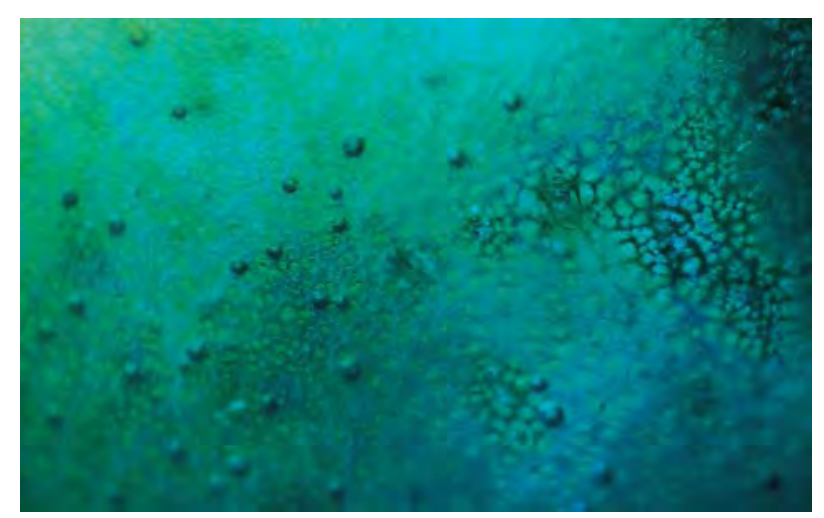

Figure 15. When the nacre was examined with an intense fiber-optic light transmitted through the crown, numerous gas bubbles in the polymer were visible through the nacre of five samples. Note that the blue polymer, illuminated through the nacre, appeared green in some. Sample courtesy of Empress Abalone Ltd.; photomicrograph by John I. Koivula, magnified 40x.

An X-ray powder diffraction pattern of a shallow surface scraping disclosed aragonite. An FTIR spectrum of a pelletized sample of a shallow surface scraping did not reveal any polymers (again, extremely thin microfilms cannot be detected by this method). IR diffuse reflectance was of limited value for detecting polymers, since the laboratory has yet to establish a significant database for pearls; however, there were no perceptible differences in the spectra for a fashioned abalone blister assemblage and an unprocessed piece of abalone shell; no polymers were indicated. The Raman spectra and ESEM images also did not reveal the presence of any recognized polymers, and the ESEM images of nacre cross-sections did not show any discernible differences in the surface structures of the blister assemblage and the unprocessed abalone shell.

EDXRF analysis revealed, in addition to the calcium $(\mathrm{Ca})$ and strontium $(\mathrm{Sr})$ expected for pearls, bromine $(\mathrm{Br})$, iodine $(\mathrm{I})$, copper $(\mathrm{Cu})$, zinc $(\mathrm{Zn})$, iron $(\mathrm{Fe})$, and sulfur $(\mathrm{S})$. Given that the nacre on this sample was relatively thin, the composition of the underlying polymer and its pigments apparently contributed to the results. To confirm this, a piece of unprocessed $H$. iris abalone shell and some blue polymer exposed on one of the samples were tested separately. $\mathrm{Ca}, \mathrm{Sr}, \mathrm{Br}$, and I were present in the shell. $\mathrm{Cu}$ and $\mathrm{Zn}$ were confined to the polymer. Small amounts of Fe were present in both the polymer and the shell. (Analyses for $\mathrm{S}$ were not conducted in these latter samples.) The EDXRF spectrum of a cultured blister pearl did not reveal any of the heavy elements (e.g., silver or tellurium) that indi- 
cate color treatments in some pearls; organic dyes cannot be detected by this method.

Durability. The McKenzies claim that the toughness and durability of their product are very good, although, as with any cultured pearl, care should be exercised in cleaning and handling. They caution against immersing the cultured blister pearl assemblages in hot water, because this may cause cracking and separation of the assembled layers. Eye-visible cracks, transparent areas revealing the colored polymer, and areas of very thin nacre affect not only the appearance, but also the durability, of the assembled cultured blister pearl. Attempts to scratch the dome surface of one sample showed it to be moderately resistant, but it yielded to a Mohs value 4 hardness point. Although some types of shell products may fade in sunlight, the McKenzies have not observed any color fading of their product. No short-term fading was observed in the half of an assembled cultured blister pearl that was left in the solar simulator for 4.5 hours (approximating nine hours of direct sunlight).

\section{MARKETING AND DISTRIBUTION}

The McKenzies debuted the Empress Pearl at the Tucson gem shows in February 1996 (figure 16). At the wholesale level, Empress Pearls are sold as "mabés," "hemispherical pearls," or "half-pearls." They are priced according to their size and their color, luster, and surface characteristics. These three attributes are the basis for the Empress Pearl "point matrix" grading system, a 100-point system that was developed in 1995 by the McKenzies specifically for their product. Points are assigned to each attribute according to its rarity and desirability. Color value is based solely on rarity.

The quality grades presently used by the company are "Gem," "A," "B," and "C." The McKenzies report that only the highest grades-"Gem," "A," and upper "B"-are sold as Empress Pearls. Approximately $4 \%$ of the material marketable under the Empress name is considered "Gem" grade, $40 \%$ is " $\mathrm{A}$ " grade, and $56 \%$ is " $\mathrm{B}$ " grade. Cultured blister pearls with lower " $\mathrm{B}$ " grades and those that fall below the " $\mathrm{B}$ " classification, termed "semi-perfect," are sold in sterling silver jewelry under the name Ocean Rainbow ${ }^{\odot}$, a product of Ocean Rainbow Ltd., Christchurch.

Empress Pearls are distributed directly to wholesalers in New Zealand, Australia, the U.S., Taiwan, England, Italy, and the Middle East. The largest

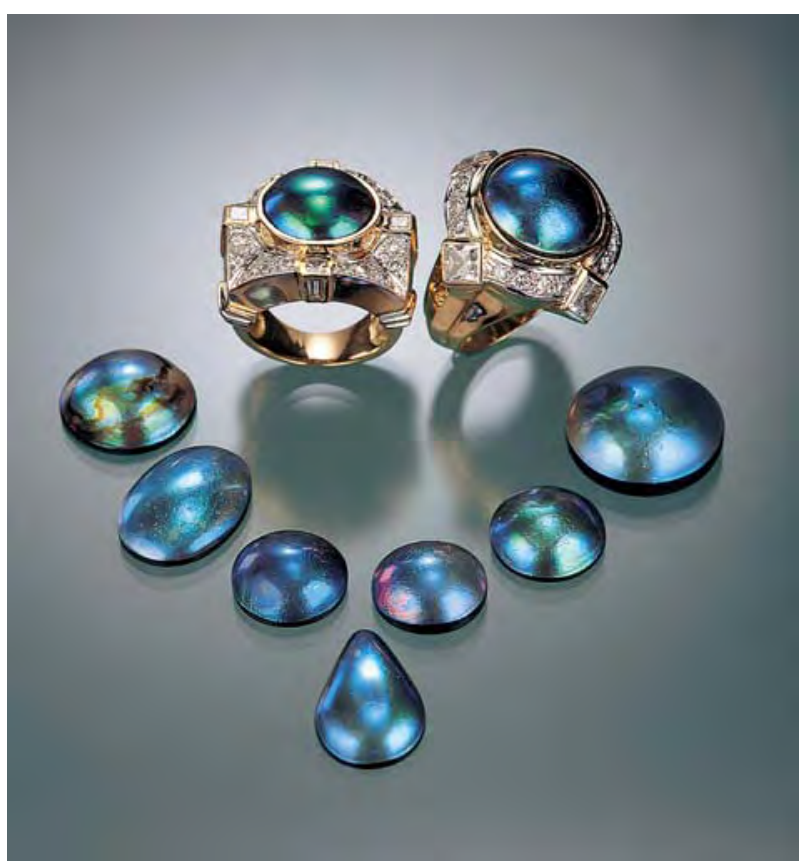

Figure 16. Empress Pearls ${ }^{\odot}$ were debuted at the 1996 Tucson Gem and Mineral Show. The 18K gold rings, each of which contains a "Gem"grade abalone "mabe" (the largest of which is about $13.5 \mathrm{~mm}$ in diameter) were designed and manufactured by $A$ e $S$ Wholesale Jewelers, Union City, New York. Samples courtesy of Empress Abalone Ltd.; photo by Robert Weldon.

market is currently the U.S., followed by New Zealand. High-quality Empress Pearls have been set in fine jewelry that incorporates high-karat gold or platinum, diamonds, and colored gems (see, e.g., cover photo, figure 1, and figure 17).

\section{WHOLE FREE-FORMED CULTURED PEARLS}

An exciting aspect of current research involves the cultivation of whole free-formed, especially spherical, cultured pearls within the body of the abalone. Over the past three and a half years, Empress Abalone Ltd. has spent approximately US $\$ 350,000$ on this research, and 2,000 abalone have been implanted with "free" spherical bead nuclei, in an attempt to produce these elusive cultured pearls.

The McKenzies have been experimenting with spherical nuclei fashioned from the shell of a species of Mississippi mussel and Pinctada maxima, the large golden-lipped oyster used to produce South Sea cultured pearls, with similar results. The optimum nucleus is $6 \mathrm{~mm}$, which is projected to yield an $8 \mathrm{~mm}$ cultured pearl. The nuclei are currently being fashioned from P. maxima. The McKenzies predict that 6-8 mm nuclei will eventu- 


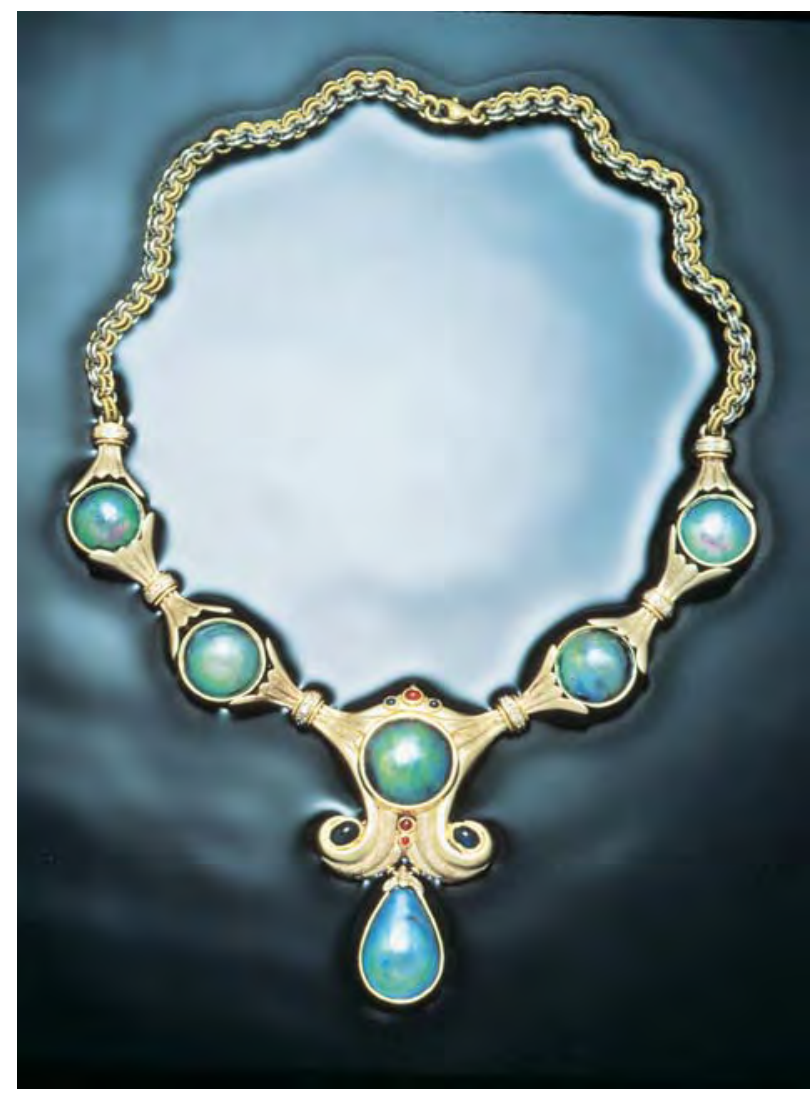

Figure 17. This $18 \mathrm{~K}$ yellow and white gold necklace contains five " $A$ "-grade round (15-18 mm) Empress Pearls and one $22 \times 15 \mathrm{~mm}$ pear shape. The necklace is accented by diamonds, rubies, and sapphires. It was designed and manufactured by Hugh Power Designs, Anchorage, Alaska. Photo (C) TKO studio, New York; courtesy of Empress Abalone Ltd.

ally be used to obtain $8-10 \mathrm{~mm}$ whole spherical cultured pearls. Larger nuclei result in a high rejection rate. One nucleus per abalone is inserted in a process that takes four to five minutes. The tools, technique, and exact location within the animal are proprietary and were developed through original research.

If an abalone's strong muscular force does not expel the loose bead nucleus, the exertion on the bead is usually enough to hinder satisfactory nacre coverage, quality, and shape. The whole free-formed cultured pearls produced to date have nacreous areas up to $2-3 \mathrm{~mm}$ thick. This nacre is thicker than that of the cultured blister pearls because the bead nucleus is a greater irritant.

According to the McKenzies, the whole freeformed cultured pearls have evolved from completely baroque shapes, most with a somewhat conical outline, to products that are more spherical. Although results are preliminary, there have been promising indications of success; the author had the opportunity to see seven of the whole free-formed beadnucleated cultured pearls at the February 1998 Tucson gem shows (figure 18).

Empress Abalone Ltd. has also been experimenting with whole free-formed tissue-nucleated cultured pearls. The tissue is implanted into the same visceral region where the free-formed bead-nucleated pearls are grown. The McKenzies describe the resulting cultured pearls as thin and curved, somewhat like a fingernail, and partially hollow; they cannot be distinguished from a natural abalone pearl on the basis of their outside appearance. To date, there is no commercial production.

\section{DISCUSSION}

Mabés. Blister pearls were the first type of cultured pearls; as early as the 13th century, various types of nuclei were implanted in oysters to be covered with mother-of-pearl, including small lead or tin forms resembling religious idols (Kammerling et al., 1990; Fankboner, 1991; Webster, 1994). More recently, hemispherical shell beads were implanted into the large Pteria penguin (Japan) and Pinctada maxima (Australia) to produce sizable blister pearls that could be assembled for use in jewelry (Crowningshield, 1982; Taburiaux, 1985; Farn, 1986). These were called mabé pearls. Typically, the blister dome would be coated from the inside with a translucent material, and a mother-of-pearl bead inserted; then any remaining voids would be filled with a colorless glue and a mother-of-pearl backing would be applied (see, e.g., Crowningshield, 1982; Taburiaux, 1985).

Today, an assembled cultured blister pearl from any type of nacreous mollusk is often referred to as a mabé, and usually only epoxy or another polymer fills the dome. Empress Pearls resemble these contemporary mabés in their assembled nature, and Empress Abalone Ltd. often refers to their products as "mabés." Although the Empress process uses a colored polymer to fill the dome, the inside surface of the nacre is not coated, as is typical of traditional mabés. In general, assembled cultured abalone blister pearls may be separated from other types by their intense coloration, high iridescence, and greenish yellow ultraviolet luminescence; the transparent nacre has unique botryoidal features and a cellular structure (visible at high magnification).

Cultured blister pearls are being or have been produced in other species of abalone, including $H$. 
rufescens, $H$. fulgens, $H$. kamtschatkana, $H$. discus, $H$. gigantea, and $H$. seiboldii. These, too, have been fashioned into "mabés." The author had the opportunity to examine a "mabé" from H. rufescens (red abalone from the west coast of North Americal that was donated to GIA by Dr. Peter Fankboner. In this sample, the nacre dome was attached directly to the mother-of-pearl and shell base with a very thin layer of transparent glue. No other layers or the dome filler were visible. The colors were pleasing, with more silver and pink hues (again, see photos in Kammerling and Fryer, 1994) compared to the more prevalent blue hue of the blisters from $H$. iris. The luster was high, with a slight satin quality.

Effects of Conchiolin on Appearance. The presence and thickness of the underlying conchiolin layer(s) determine the quality of light and color reflected back to the observer. The blue polymer did not affect the face-up appearance of those assemblages that have conchiolin layers sufficiently thick to block the passage of light. The conchiolin acted as a mirror, reflecting normal overhead light back through the nacre toward the observer for maximum light return, color, and iridescence. The faceup color of samples that contained thinner conchiolin layers could possibly be slightly affected by the blue polymer; however, even moderately thin layers of conchiolin acted as a mirror, and the colored polymer in these pearls could only be discerned with intense light. Examination of the sawn blister dome that was half-filled with blue polymer and half-filled with colorless polymer confirmed this conclusion. Face-up examination of both halves revealed no discernible color difference (figure 12).

Conversely, absence of this conchiolin layer diminishes the potentially strong and appealing visual effects; assemblages without a conchiolin layer, or with a very thin conchiolin layer, allowed light to enter the polymer filling. These pearls not only showed less intense color and brilliance, but the light passing into the colored polymer affected the face-up color of the pearl. On careful examination in reflected light and with the unaided eye, this was evident on a sawn reject sample and on the lowest-quality commercial product; they both showed a bluish background color that was at least partially due to the polymer, but the extent of impact could not be determined.

Examination for Surface Treatments. The high luster combined with the transparent nacre have led

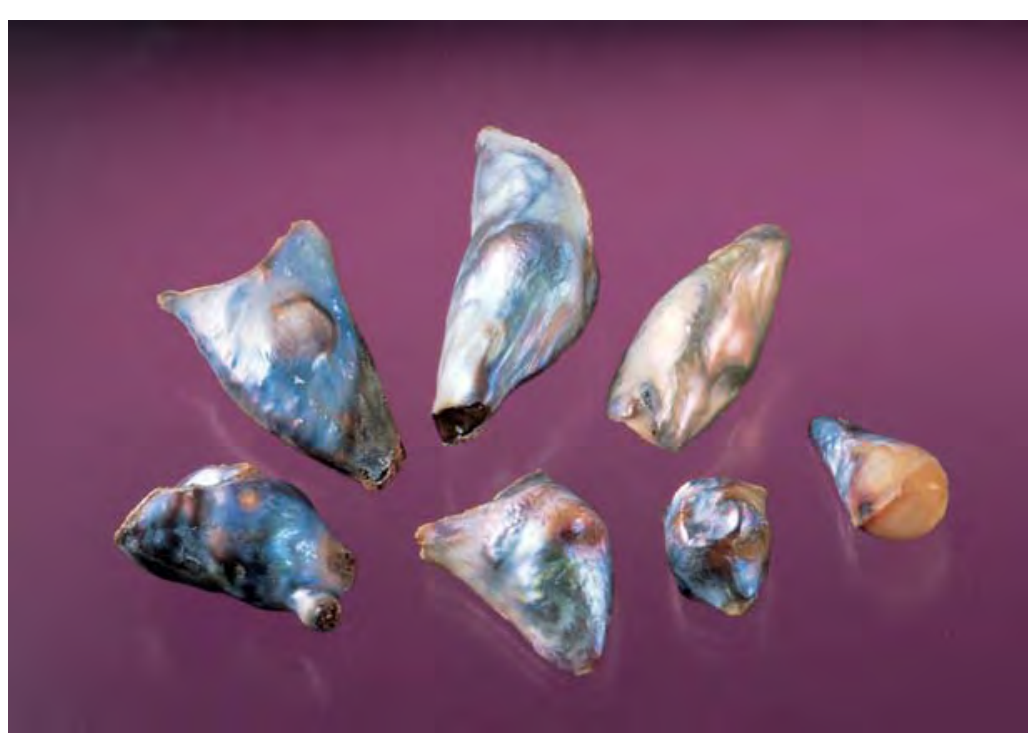

Figure 18. The first attempts at culturing whole free-formed bead-nucleated abalone pearls produced these irregular shapes in February 1998. Pressure exerted by the abalone on the bead commonly prevents the nacre from covering the entire nucleus. Samples courtesy of Empress Abalone Ltd.; photo by Maha DeMaggio.

some people to suspect a polymer coating on these "mabés." Also, the vivid colors can mislead one to believe they are dyed (and some dyed traditional mabés resemble this abalone product [R. Kane, pers. comm., 1998]). No coatings or dyes were detected in the course of this study. Not all samples were tested by advanced techniques, and the possibility exists that an extremely thin polymer microfilm or an organic dye could defy detection by all the testing techniques available to the author; however, the vibrant colors, transparency, and ability to achieve a high luster are properties that are inherent to abalone nacre.

Durability. Although comprehensive durability testing was not performed on the Empress product, mabés in general are relatively soft (hardness 3.5-4), and their domes have moderately thin nacre. Care must be taken during wear, as a sharp blow could crack them. It is the author's opinion that the product lends itself best for use in pendants, enhancers, necklace clasps, brooches, and earrings, where the threat of damage is reduced. Rings are only recommended for occasional wear.

\section{CONCLUSION}

Empress Abalone Ltd. is commercially producing cultured blister pearls with vibrant colors and a 
rainbow-like iridescence that are unique to New Zealand's H. iris abalone. In 1997, 6,000 commercial-quality cultured blister pearls were harvested, in sizes up to $12 \mathrm{~mm}$ in diameter, and a similar quantity is expected for 1998. In an assemblage process similar to that used for mabés from traditional pearl oysters, the cultured blister pearls are cut from the shell, filled with a blue polymer, backed with mother-of-pearl, and buffed to a high luster. Examination of 22 of these "mabés" revealed the various components that are used to assemble the product, as well as the character of the nacre. Conchiolin plays an important role in the face-up appearance of the "mabés." Where the conchiolin layer is very thin or absent, the blue polymer used to fill the dome can affect the color appearance of the nacre; whereas the presence of thicker layers of conchiolin optimizes the naturally vivid colors and iridescence. Examination with magnification of all samples, and advanced testing of some, revealed no evidence of any surface treatment.

These abalone "mabés" are priced according to their size, color, luster, and surface blemishes. Empress Abalone Ltd. markets the finer quality material as Empress Pearls worldwide (Empress Abalone Pearls in the U.S.). The lower quality mate- rial is marketed under the name Ocean Rainbow. The abalone product, like other mabés, should be worn and treated with care.

Research is ongoing, and the prospects for decreased mortality rates, increased production yields, and greater control over nacre deposition appear good. Methods for the commercial production of whole free-formed bead- and tissue-nucleated cultured abalone pearls are being explored.

Acknowledgments: The author thanks Liz and Michael McKenzie, of Empress Abalone Ltd., Christchurch, New Zealand, for providing information, samples, and photos; Betty Sue King of King's Ransom, Sausalito California, for providing samples; Shane McClure of GIA GTL for photomicrography, suggestions, and support; Dino DeGhionno of GIA GTL for X-ray powder diffraction analysis; Sam Muhlmeister of GIA Research for EDXRF analysis; Shane Elen of GIA Research for producing FTIR diffuse reflectance and Raman spectra; Claus Hedegaard for producing ESEM images; Dr. Peter V. Fankboner for information; and staff members at the Richard T. Liddicoat Library and Information Center, and Leila Dooley of the Carlsbad City Library, for assistance with the literature search.

\section{REFERENCES}

Bigger abalone pearls in 1992. (1991) Hong Kong Jewellery, Vol. 2, No. 50, p. 90.

Bostwick L.P. (1936) Growing pearls in the laboratory. The Gemmologist, Vol. 5, No. 54, pp. 143-149.

Brown G. (1985) The abalone and its pearls. Australian Gemmologist, Vol. 15, No. 11, pp. 400-403.

Brown G. (1997) New Zealand's Empress Pearl ${ }^{\circledR}$-An abalone pearl par excellence. Jewellery World, Vol. 16, No. 2, pp. 36-38.

Cox K.W. (1962) California abalones, family Haliotidae. California Department of Fish and Game Fish Bulletin, No. $118,133 \mathrm{pp}$.

Cropp D. (1997) Abalone pearls from Bass Strait. Australian Gemmologist, Vol. 19, No. 9, pp. 375-379.

Crowningshield G.R. (1982) Cultured 3/4 blister pearls. Gems «) Gemology, Vol. 18, No. 1, pp. 36-38.

Fankboner P.V. (1991) Pearl culture in abalone. Infofish International, No. 4/91, July/August, pp. 52-55.

Fankboner P.V. (1994) Process for Producing Pearls in Abalone and Other Shell-Bearing Molluska and Nucleus Used Therewith. U.S. Patent Number 5,347,951, Sept. 20, 33 pp.

Fankboner P.V. (1995) Abalone pearls: Natural and cultured. Canadian Gemmologist, Vol. 16, No. 1, pp. 3-8.

Farn A.E. (1986) Pearls: Natural, Cultured and Imitation. Butterworth-Heinemann Ltd., Oxford, England, 150 pp.

Haldane D. (1992) The mystery of the missing mollusks. Los Angeles Times Magazine, January 5, pp. 23-26.
Howorth P.C. (1978) The Abalone Book. Naturegraph Publishers, Happy Camp, CA, 80 pp.

Kammerling R.C., Koivula J.I., Kane R.E. (1990) Examination of an interesting cultured blister pearl. Australian Gemmologist, Vol. 17, No. 5, pp. 174-175.

Kammerling R.C., Fryer C.W. (1994) Lab notes: Abalone "mabé" pearl. Gems et Gemology, Vol. 30, No. 4, p. 268.

McGraw-Hill (1987) Encyclopedia of Science and Technology. 6th ed. McGraw-Hill Book Co., New York, pp. 4, 22-23, 587-588.

McKenzie L. (1996) The Empress Pearl ${ }^{\odot}$-A New Zealand cultured half-pearl. Australian Gemmologist, Vol. 19, No. 8, pp. 336-338.

McLean J.H. (1969) Marine Shells of California. Los Angeles County Museum of Natural History Science Series 24, Zoology No. 11, 104 pp.

Nieson T.M. (1994) Beachcomber's Guide to Southern California Marine Life. Gulf Publishing Co., Houston, TX, $192 \mathrm{pp}$.

SFU marine biologist claims world record for culturing motherof-all (abalone)-pearls (1996) Simon Fraser University News, Jan. 18, pp. 1-2.

Taburiaux J. (1985) Pearls: Their Origin, Treatment 4 Identification. Chilton Book Co., Radnor, PA, 247 pp.

Ward F. (1998) Pearls. Gem Book Publishers, Bethesda, MD, 64 pp.

Webster R. (1994) Gems: Their Sources, Descriptions and Identification, 5th ed. Rev. by Peter Read, ButterworthHeinemann Ltd., Oxford, England, pp. 500-558. 